\section{Penguin breeding failure and mortality}

Since both your account of the penguin mortality in the Falklands Islands last spring (Lyster, 1986; Anon., 1986) and British representations to the United Nations General Assembly to justify assumption of control over the local fisheries appear to have missed a comment on the reports of the incident in Nature (Rich, 1986a,b; Bourne, 1986), it may be useful to enlarge upon it.

My colleague W. F. Curtis and I also saw a limited number of dead and dying rockhopper penguins Eudyptes chrysocome (a scientific name that takes priority over $E$. crestatus) during the course of observations on seabirds around the Falklands between February and May 1986 (Bourne and Curtis, 1986). Most of the mortality, which only involved a fraction of the estimated breeding population of five million birds, occurred towards the end of the breeding season, when first some young birds and subsequently some of the moulting adults appeared to have starved to death (Dowse, 1986).

We failed to notice abnormal mortality among the gentoo penguins Pygoscelis papua, which are also said to have been affected to a lesser extent in the Falklands, or the Magellanic penguins Spheniscus magellanicus, which are apparently the only species breeding in the area where penguin mortality was also reported along the adjacent coast of Argentina (Rich, 1986b). The closely related jackass penguins $S$. demersus also appear to have had a poor breeding season in South Africa (Crawford et al., 1986), and Yolanda van Heezik of Otago University reports (in litt.) that a shortage of fish was followed by both chick and adult mortality and a decline in the population of the world's rarest penguin species, the yellow-eyed penguin Megadyptes antipodes, which breeds in similar latitudes in New Zealand.

It seems rather doubtful that all these widespread breeding failures, followed in some cases by adult mortality, could be due to the simultaneous onset of competition for food from fishermen. In the Falklands the only previous investigation of the rockhoppers' diet (Croxall et al., 1985) indicated that they were feeding on a small species of squid of the genus Teuthowenia and various plankton, which are not yet taken by fishermen, though $\mathrm{Dr}$ 112
P. J. Moors (1986 and in litt.) reports that at Campbell Island, south of New Zealand, where they have already been declining for nearly half a century, longer than there has been an overfishing problem, they also take small blue whiting Micromesistius poutassou, which is one of the species most affected by overfishing around the Falklands.

It is also notable that the summer of $1985-86$ was associated with a considerable influx of northern warm-water seabirds to the Falklands, including the first recorded Cory's and little shearwaters Calonectris diomedea and Puffinus assimilis and Franklin's and band-tailed gulls Larus pipixcan and L. belcheri (Bourne and Curtis, 1986). It seems possible that all these birds may have been affected by some widespread oceanic fluctuation around the northern margin of the Southern Ocean resembling the El Nino Southern Oscillation of the tropical Pacific, where the periodic appearance of warm water is associated with widespread seabird breeding failure followed by adult mortality and dispersal (Schreiber and Schreiber, 1984).

\section{References}

Anon. 1986. Penguin mortality in the Falklands. Oryx, 20, 206-207.

Bourne, W.R.P. 1986. Penguin deaths questioned. Nature (Lond.), 322, 679.

Bourne, W.R.P. and Curtis, W.F. 1986. South Atlantic bird islands. Sea Swallow, 35, 24-34.

Crawford, R.J.M., Williams, A.J. and Crawford, P.B. 1986. A note on mortality of seabirds off western southern Africa, October 1985-February 1986. S. Afr. J. mar. Sci. 4, 119-123.

Croxall, J.P., Prince, P.A., Baird, A. and Ward, P. 1985. The diet of the Southern Rockhopper Penguin Eudyptes chrysocome chrysocome at Beachene Island, Falkland Islands. J. Zool. Lond. 206, 485-496.

Dowse, A. The 1986 penguin wreck: a summary. Falkland Island Trust News, 2, 1-2.

Lyster, S. 1986. Penguin Deaths Worry. Falkland Islands Foundation Newsietter, 5, 2-4.

Moors, P.J. 1986. Decline in the numbers of Rockhopper Penguins at Campbell Island. Polar Record, 23, 69-73.

Rich, V. 1986a. Opinion divided on penguin deaths. Nature (Lond.), 322, 4.

Rich, V. 1986b. More dead penguins. Nature (Lond.), 322 , 296.

Schreiber, R.W. and Schreiber, E.A. 1984. Central Pacific Seabirds and the El Niño Southern Oscillation, 1982 to 1983 perspectives. Science, 225, 713-716.

W. R. P. Boume, 3 Contlaw Place, Milltimber, Aberdeen ABI ODS, UK.

Oryx Vol 21 No 2. April 1987 